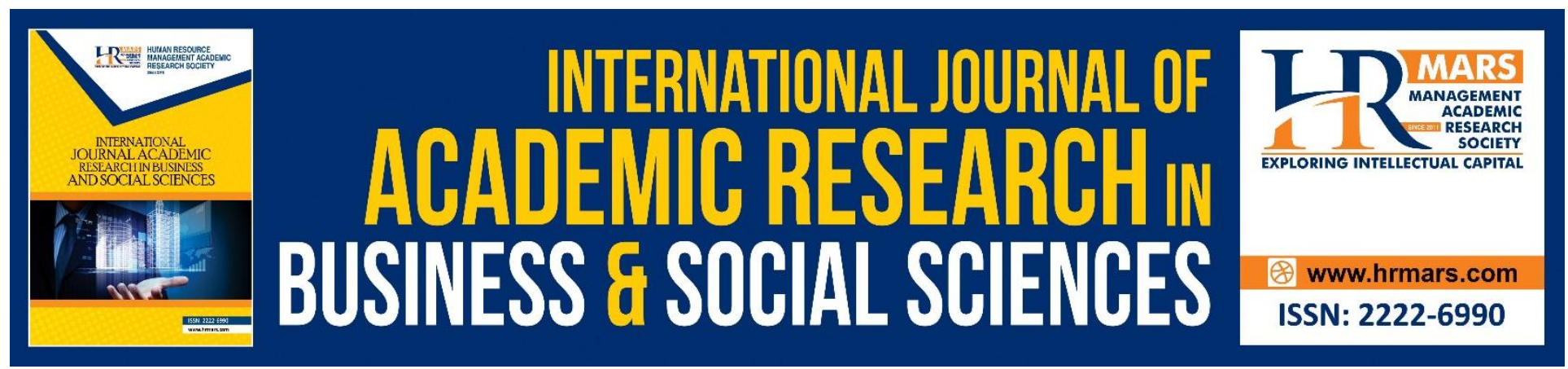

\title{
The Formulation of a Critical Data Management Framework for Situations Facing Disasters through the Delphi Technique
}

Nor Hasbiah Ubaidullah, Aslina Saad, Jamilah Hamid, Nazre Abdul Rashid, Zulkifley Mohamed, Mohamadisa Hashim

To Link this Article: http://dx.doi.org/10.6007/IJARBSS/v8-i9/4691

DOI: $10.6007 /$ IJARBSS/v8-i9/4691

Received: 02 August 2018, Revised: 07 Sept 2018, Accepted: 29 Sept 2018

Published Online: 09 October 2018

In-Text Citation: (Ubaidullah et al., 2018)

To Cite this Article: Ubaidullah, N. H., Saad, A., Hamid, J., Rashid, N. A., Mohamed, Z., \& Hashim, M. (2018). The Formulation of a Critical Data Management Framework for Situations Facing Disasters through the Delphi Technique. International Journal of Academic Research in Business and Social Sciences, 8(9), 1193-1210.

Copyright: (C) 2018 The Author(s)

Published by Human Resource Management Academic Research Society (www.hrmars.com)

This article is published under the Creative Commons Attribution (CC BY 4.0) license. Anyone may reproduce, distribute, translate and create derivative works of this article (for both commercial and non-commercial purposes), subject to full attribution to the original publication and authors. The full terms of this license may be seen

at: http://creativecommons.org/licences/by/4.0/legalcode

Vol. 8, No. 9, September 2018, Pg. 1193 - 1210

Full Terms \& Conditions of access and use can be found at http://hrmars.com/index.php/pages/detail/publication-ethics 


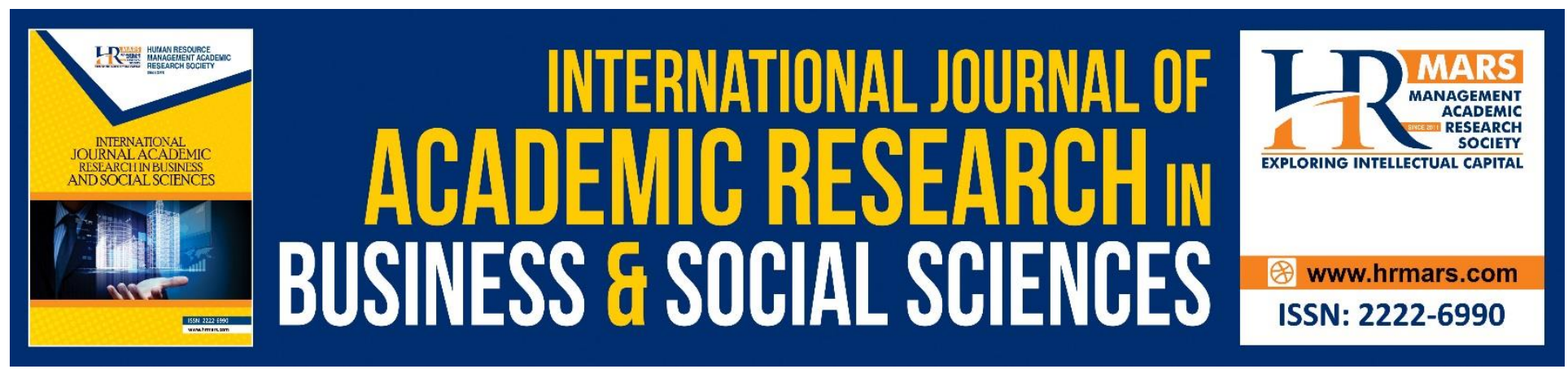

\title{
The Formulation of a Critical Data Management Framework for Situations Facing Disasters through the Delphi Technique
}

\author{
Nor Hasbiah Ubaidullah a, Aslina Saad a, Jamilah Hamid a, Nazre \\ Abdul Rashid a, Zulkifley Mohamed ${ }^{b}$, Mohamadisa Hashim ${ }^{c}$ \\ ${ }^{a}$ Computing Department, Faculty of Arts, Computing and Creative Industry, \\ ${ }^{b}$ Mathematics Department, Faculty of Science and Mathematics, \\ ' Geography Department, Faculty of Human Sciences, \\ Universiti Pendidikan Sultan Idris, 35900 Tg. Malim Perak, Malaysia \\ Corresponding Author: Email address: hasbiah@fskik.upsi.edu.my
}

\begin{abstract}
A study on several organizations in one of the districts of Kelantan that was severely affected by the massive floods in 2014 highlights a number of problems in managing data, notably critical data, owing to the lack of a standard operating procedure (SOP) that could be used as guidelines for data storage, data loss, and data inconsistency between organizations. Admittedly, there are several data management frameworks available, but in general, they are less effective for the management of data in times of crisis due to natural disasters. In view of this predicament, a critical data management framework was developed to serve as guidelines in dealing with the above prevailing issues. More specifically, the aim of this study is to identify and validate the components and elements of an appropriate assessment instrument using the Delphi technique to help formulate such a framework in dealing with the management of critical data in situations facing disasters. In this study, the validation of several selected components and elements through the Delphi technique was carried out in two rounds involving a panel of experts, consisting of three data managers, three ICT administrators from the public sector, and three academicians. The findings of the validation process showed that all the experts unanimously accepted and validated 10 components that were deemed vital for the formulation of the proposed critical data management framework. In fact, the formulation of the proposed framework was more compressive and holistic by focusing not only on the general aspects of data management but also on the critical aspects of disaster management, of which the latter could help organizations to handle important data in times when disasters occur unpredictably. Equipped with such a comprehensive framework, the researchers would be able to develop a
\end{abstract}


critical data management system prototype to help organizations, with which organizations could use to help manage their important, valuable data in critical, precarious situations.

Keywords: Assessment, Critical Data, Data Management Framework, Disasters, Delphi Technique, Validation.

\section{Introduction}

Critical data are data that have critical impact on peoples worldwide that need a high level of security (Gary, 2011). Such data are different based on organizations and have to be managed effectively to avoid business failures and disruptions that lead to loss of profit. Thus, good data management entails organizations to identify data that are critical and to define such data in detail. Clearly, identifying critical data is a data administration practice that helps organizations to improve profits, customer satisfaction, and product quality. Disasters, such as floods, fire outbreaks, earthquakes, can occur unpredictably that can destroy unprotected data, causing significant losses. In this regard, Haraguchi and Lall (2015) study on the impact of floods on the global economy highlighted the losses of physical assets and data experienced by various sectors in such events.

More revealingly, a study by Nor Hasbiah et al., (2017) on the management of critical data of several organizations showed several problems, such as the absence of a standard SOP to serve as guidelines, data storage, data loss, and data inconsistency among organizations. In particular, they found one recurring problem that was primarily attributed to the use of existing data management framework which were discussed by Australian National Data Service (2017), Beaujardiere (n.d.) and Patricia (2014). As such, the development of an effective data management framework needs to be addressed to serve as guidelines for both general and critical data in critical conditions, such as in disasters.

In general, there are several data management frameworks that can serve as guidelines. Arguably, despite the many available frameworks, they seem to share some common components. In fact, most of them are more appropriate for general data management in normal situations (Australian National Data Service, 2017; Beaujardiere, n.d.; Patricia, 2014), lacking the focus on management of critical data in disastrous situations. Obviously, existing frameworks have been developed without taking vital aspects or components in critical situations into account. As such, a more effective data management framework was developed in this study that took into account the important components that are deemed relevant to disastrous situations, which can serve as guidelines for managing critical data in facing critical situations.

Therefore, validity testing was needed to ascertain the acceptability of components of such a framework through a scientific approach. More specifically, in this study, the Delphi technique was used to elicit input required to validate the selected components and elements of the data management framework. The findings of this testing helped the researchers to formulate an effective framework of data management that could be used in critical situations.

This study contributes to the formulation of a critical data management framework for situations facing disasters. 


\section{Methodology}

In essence, research methodology is a systematic approach used in seeking a solution to a research question or to achieve a research objective (Khotari, 2004). In this regard, this study uses the Delphi technique in order to achieve a research objective. Particularly, the Delphi technique serves as an important instrument (tool) in qualitative studies to help collect and analyze the views of practitioners regarding a specific area of research. The Delphi technique operates by searching for an agreement or consensus using assessment instruments or questioners, which are administered in several rounds to collect appropriate data from a selected panel of experts (Hsu \& Sandford, 2007). Cohran (1983) contends that the Delphi technique has been proven to be a reliable technique in many qualitative studies, having potent utility to solve problems, make effective decisions, and reach important consensus in a wide variety of areas. Thus, this technique is an excellent method for the evaluation of qualitative research encompassing a wide variety of disciplines, such as education, technology, science, and engineering. In this regard, Nworie (2011) states that the Delphi technique is the investigation methodology used to screen and identify relevant factors and to obtain agreement among experts in a particular field of study. In this study, two rounds of the review process were done in order to elicit the consensus pertaining to the relevancy of the selected components from the experts.

\section{Appointment of Experts}

According to Cantril, Slbbald, and Beutow (1996), experts are people who have vast experience and immense knowledge on particular topics. In this study, the selection of the panel of experts was based on their expertise and experiences in areas related to data management. Specifically, the expert panel consisted of academicians from several government sectors and data management managers of the industry, who collectively had at least 15 years of experience in the field of data management. However, choosing the suitable numbers of experts that are appropriate for the implementation of the Delphi technique remains a contentious issue. For example, Okoli and Powlowski (2004) suggest the number of participants be between 10 and 18 . In contrast, Armstrong (1975) recommends a sample size consisting of a number of respondents, ranging from 5 to 20, depending on the availability of experts, the quality of feedback, and also the costs involved. On a more relaxed criterion, according to Brockhoff (1975), under certain conditions, the Delphi technique is also appropriate even when only four respondents are available. This liberal view of the sample size is also shared by Chuls (2014), who stresses that the number of participants ultimately depends on the number of topics, fields, feedback, and other prevailing issues. On a positive note, Brockhoff (1975) and Rowe and Wright (1999) found that there were no significant differences in the consensuses between group panels consisting of three, five, seven, nine, or eleven members.

Taking cognizance of the above arguments, 9 experts were recruited for this study comprising a balanced representation of academic, industrial, and governmental sectors. Such a number is consistent with the recommended range of sizes, from 8 to 10, in areas of research that lack adequate population (Armstrong, 1975). Specifically, the panel of experts consisted of three industrial practitioners (who were data managers), three industrial practitioners (who were engaged with public agencies), and three academicians (who were involved in information 
INTERNATIONAL JOURNAL OF ACADEMIC RESEARCH IN BUSINESS AND SOCIAL SCIENCES

Vol. 8, No. 9, Sept. 2018, E-ISSN: 2222-6990 @ 2018 HRMARS

systems management). Table 1 summarizes the panel of experts' positions, years of working experience, and categories of service.

Table 1: The panel of experts' designations, years of working experience, and categories of service

\begin{tabular}{|c|c|c|c|}
\hline Panel & Designations & $\begin{array}{c}\text { Working } \\
\text { Experience }\end{array}$ & Category \\
\hline $\begin{array}{c}\text { Panel } \\
1\end{array}$ & Academician & 15 & Public \\
\hline $\begin{array}{l}\text { Panel } \\
2\end{array}$ & Academician & 20 & Public \\
\hline $\begin{array}{c}\text { Panel } \\
3\end{array}$ & Academician & 15 & Public \\
\hline $\begin{array}{c}\text { Panel } \\
4\end{array}$ & ICT Administrator & 21 & Public \\
\hline $\begin{array}{c}\text { Panel } \\
5\end{array}$ & ICT Consultant & 29 & Public \\
\hline $\begin{array}{c}\text { Panel } \\
6\end{array}$ & ICT Administrator & 15 & Public \\
\hline $\begin{array}{c}\text { Panel } \\
7\end{array}$ & Data manager & 18 & Private \\
\hline $\begin{array}{c}\text { Panel } \\
8\end{array}$ & Data manager & 20 & Private \\
\hline $\begin{array}{l}\text { Panel } \\
9\end{array}$ & Data manager & 23 & Private \\
\hline
\end{tabular}

\section{Assessment Instrument}

The process of developing the assessment instrument started with a review of existing information on relevant components and elements of data management framework from a variety of sources. In this process, important components from multiple sources, such as journal articles, technical reports, and organization websites, were shortlisted and screened to obtain a list of basic components of a data management framework. As such, four participants with sufficient experience in data management were chosen in the pilot study to verify the assessment instrument. Essentially, each item of the assessment instrument was rated along a 5-point Likerttype scale, which measured the degree of agreements of the participants as shown in Table 2. Through this pilot study, several suggestions were made by the participants to improve the instrument by reorganizing the presentation of the assessment instrument. Predictably, the reliability of the assessment instrument was further improved by incorporating their suggestions into the assessment instrument. 
INTERNATIONAL JOURNAL OF ACADEMIC RESEARCH IN BUSINESS AND SOCIAL SCIENCES

Vol. 8, No. 9, Sept. 2018, E-ISSN: 2222-6990 @ 2018 HRMARS

Table 2: The rating scale of the experts' opinions

\begin{tabular}{cl}
\hline Scale & Indicator \\
\hline 1 & Highly irrelevant \\
2 & Likely irrelevant \\
3 & More or less irrelevant \\
4 & Likely relevant \\
5 & Highly relevant \\
\hline
\end{tabular}

\section{The Delphi Technique}

To date, the Delphi technique has been widely used by researchers in eliciting relevant technical opinions from experts (Nworie, 2011; Hsu \& Sandford, 2007; Cochran, 1983). In this study, the same technique was used to analyze such feedback elicited from a panel of practitioners, the process of which was carried out in two rounds as shown in Figure 1.

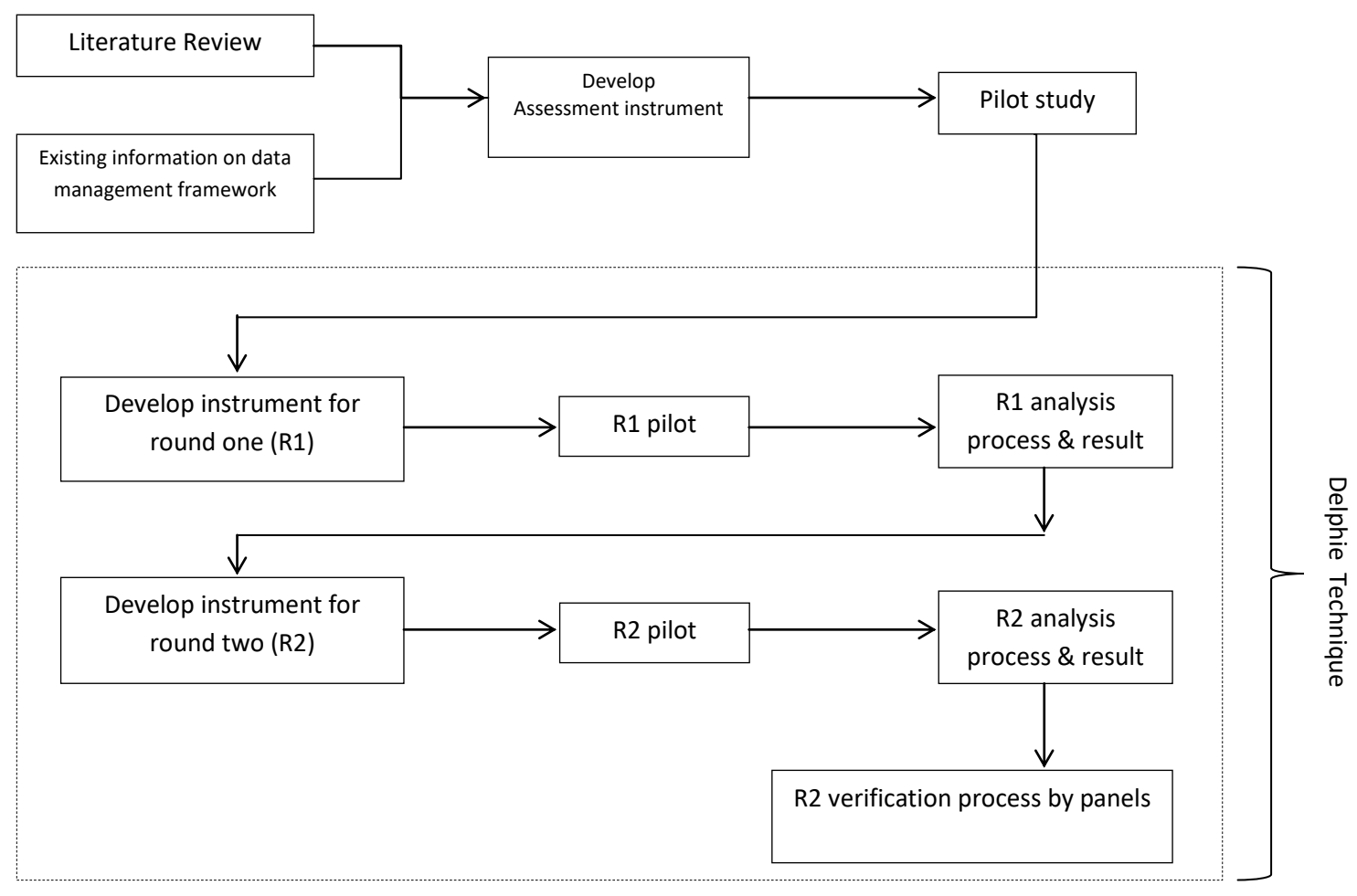

Figure 1: The process of the Delphi technique performed in the study

\section{The first round of the review process of the Delphi technique}

In the first round of the review process of the Delphi technique, the assessment instrument consisting of eight components with 38 elements was sent to the selected experts through formal 
letters and emails to elicit their feedback. Interestingly, the experts also provided relevant information, which helped further improve the assessment instrument by adding two new components and several elements to help revise the assessment instrument for the second round of the process of the technique.

\section{The second round of the review process of the Delphi technique}

The second round of the review process was carried out after the researchers had completed the analysis of the data obtained from the first-round process. The goal of the second round or any other subsequent rounds is to achieve consensus based on the panel members' responses (Chu \& Hwang, 2007). For this study, the researchers redistributed all the panel members' first-round responses and asked them to provide appropriate comments or feedback. Subsequently, the second round of the review process of the Delphi technique was completed when all assessment instrument items had been either accepted or rejected.

The second round of the review process entailed the experts to evaluate and complete their feedback based on the updated assessment instrument with additional components. For such evaluation, the acceptance or the rejection of a component was based on the cut-off point of 3.5, which was based on the continuum of ratings, ranging from " 1 " to " 5 ", as being highly irrelevant and highly relevant indicators, respectively. As such, indicators attaining mean scores of 3.5 and above were accepted; while those with mean scores of less than 3.5 were rejected (Chu \& Hwang, 2007; Egan \& Jone, 1997; Hai \& Hai, 2011). Ultimately, this evaluation rendered the assessment instrument with 10 components and 44 elements.

\section{Results and Discussion}

The findings of this study consist of two types of data, namely data obtained from the first round and the second round of the process of the Delphi method. For the former, it was found that there were several elements of the proposed framework that had to be either added (accepted) or discarded (rejected). In addition, the same data indicated that two components had to be added to the framework, namely the security component and the disasters management component. Table 3 summarizes the added and discarded elements of the proposed framework for critical data management. 
Table 3: The components and elements of the proposed critical data management framework after the first round of the Delphi method

\begin{tabular}{|c|c|c|}
\hline Components of data management & $\begin{array}{c}\text { Status of element } \\
\text { (accepted/ } \\
\text { rejected) }\end{array}$ & $\begin{array}{c}\text { New element } \\
\text { (refined/added) }\end{array}$ \\
\hline \multicolumn{3}{|l|}{ K1: Data architecture } \\
\hline 1. Data are shared assets & Rejected & \\
\hline 2. Data security is based on the level of complexity of data & Rejected & \\
\hline 3. Data are defined consistently based on simple vocabulary & Accepted & \\
\hline 4. Data are valuable assets for organizations & Rejected & \\
\hline 5. Data analysis is performed to elicit useful information & Accepted & \\
\hline \multicolumn{3}{|l|}{ K2: Data management principles } \\
\hline $\begin{array}{l}\text { 1. Data can be accessed according to the allowable access } \\
\text { rights }\end{array}$ & & Refined \\
\hline 2. Data can be easily searched, identified, and documented & Accepted & \\
\hline 3. Data can be saved and reused & Accepted & \\
\hline $\begin{array}{l}\text { 4. Data can be managed by the management steward or data } \\
\text { custodian }\end{array}$ & & Refined \\
\hline $\begin{array}{l}\text { 5. Data quality control is needed to ensure data will be } \\
\text { consistent, accurate, available, and complete }\end{array}$ & Accepted & \\
\hline 6. Data access must support audit trails & & Added \\
\hline \multicolumn{3}{|l|}{ K3: Data lifecycle management } \\
\hline 1. Acquisition and selection process & Accepted & \\
\hline 2. Access, utilization, and dissemination process & Accepted & \\
\hline 3. Analysis, evaluation, and visualization process & Accepted & \\
\hline 4. Archiving process & Accepted & \\
\hline 5. Verification process and data cleaning & Accepted & \\
\hline 6. Data maintenance process & Accepted & \\
\hline \multicolumn{3}{|l|}{ K4: Policy and procedure } \\
\hline 1. Explanation of data ownership & & Refined \\
\hline 2. Explanation of data saving and security & Accepted & \\
\hline 3. Explanation of responsibilities and parties concerned & Accepted & \\
\hline 4. Definition of used terminology & Accepted & \\
\hline 5. Explanation of the rights for data access & & Refined \\
\hline $\begin{array}{l}\text { 6. Verification of data by data steward to guarantee the quality } \\
\text { and integrity of data }\end{array}$ & & Refined \\
\hline \multicolumn{3}{|l|}{ K5: Metadata } \\
\hline 1. Versatility (Metadata have multi functions) & Accepted & \\
\hline 2. Modularity (Metadata can be divided into sub-modules) & Accepted & \\
\hline 3. Extensibility (Metadata can support addition of elements) & Accepted & \\
\hline 4. Granularity (Levels of metadata can be explained) & Accepted & \\
\hline 5. Platform (Metadata can function on the latest platform) & Accepted & \\
\hline \multicolumn{3}{|l|}{ K6: Support services } \\
\hline $\begin{array}{l}\text { 1. Support for automatic data management for all service } \\
\text { departments }\end{array}$ & Accepted & \\
\hline 2. Support for data collection by authorized parties & & Refined \\
\hline
\end{tabular}


INTERNATIONAL JOURNAL OF ACADEMIC RESEARCH IN BUSINESS AND SOCIAL SCIENCES Vol. 8, No. 9, Sept. 2018, E-ISSN: 2222-6990 @ 2018 HRMARS

\begin{tabular}{|c|c|c|}
\hline $\begin{array}{l}\text { 3. Support for Data saving and publication for organizational } \\
\text { research }\end{array}$ & Rejected & \\
\hline $\begin{array}{l}\text { 4. Support for duplicated offsite data, such as mirror } \\
\text { duplicates, Data Recovery Center (DRC) or external data } \\
\text { (kept by external agencies) }\end{array}$ & & Added \\
\hline 5. Support for policy related to data duplication & & Added \\
\hline \multicolumn{3}{|l|}{ K7: Data sources } \\
\hline 1. Data are shared assets & Accepted & \\
\hline $\begin{array}{l}\text { 2. Data sources and data integrity need to be maintained and } \\
\text { protected }\end{array}$ & Accepted & \\
\hline $\begin{array}{l}\text { 3. Data have to be managed as important sources for } \\
\text { organizations to help maintain the quality and standard of } \\
\text { data }\end{array}$ & Accepted & \\
\hline \multicolumn{3}{|l|}{ K8: Assessment - data maturity model } \\
\hline $\begin{array}{l}\text { 1. Level 1: Unaware (Data are limited and the accuracy and } \\
\text { validity of data are not checked) }\end{array}$ & Accepted & \\
\hline $\begin{array}{l}\text { 2. Level 2: Nascent (Data collection is good, but the collected } \\
\text { data are not consistent and hardly updated) }\end{array}$ & Accepted & \\
\hline $\begin{array}{l}\text { 3. Level 3: Learning (Studies on the value, relevancy, and } \\
\text { usage of data are performed despite some minor data } \\
\text { errors) }\end{array}$ & Accepted & \\
\hline $\begin{array}{l}\text { 4. Level 4:Developing (The needs for data are defined and } \\
\text { collected systematically) }\end{array}$ & Accepted & \\
\hline $\begin{array}{l}\text { 5. Level 5: Mastering (Values and usage of data are well- } \\
\text { understood) }\end{array}$ & Accepted & \\
\hline \multicolumn{3}{|l|}{ K9: Security and access } \\
\hline 1. Data have can be shared and accessed & & Added \\
\hline 2. Data security is based on the level of data complexity & & Added \\
\hline 3. Confidential data have to be encrypted & & Added \\
\hline \multicolumn{3}{|l|}{ K10: Disasters management } \\
\hline 1. Phase 1: Assessment of disasters & & Added \\
\hline 2. Phase 2: Activation of recovery plans & & Added \\
\hline $\begin{array}{l}\text { 3. Phase 3: Operational replacement platform/recovery of } \\
\text { main platform }\end{array}$ & & Added \\
\hline 4. Phase 4: Testing and maintenance & & Added \\
\hline
\end{tabular}

**Italicised words indicate sentences that were refined or added

In addition to the suggested refinement, addition, and elimination of several elements of the assessment instrument, some of the experts also recommended that the definition of data management had to be expressed early on the instrument. All the comments and suggestions made by the experts during the first round of the Delphi process were incorporated into the instrument for the second round of the same method as summarized in Table 4. 
Table 4: The components and elements of the proposed critical data management framework elicited from the panel in the second round of the Delphi method

\begin{tabular}{|c|c|c|c|c|c|c|c|c|c|c|c|c|}
\hline \multirow[t]{2}{*}{$\begin{array}{l}\text { Components of } \\
\text { data } \\
\text { management }\end{array}$} & & & Exp & ert & asse & ssm & nen & & & \multirow[t]{2}{*}{$\begin{array}{l}\text { Mea } \\
n \\
\text { scor } \\
\text { e }\end{array}$} & \multirow[t]{2}{*}{$\begin{array}{c}\text { Std } \\
\text { devia } \\
\text { tion }\end{array}$} & \multirow[t]{2}{*}{ Status } \\
\hline & 1 & 2 & 3 & 4 & 5 & 6 & 7 & 8 & 9 & & & \\
\hline \multicolumn{13}{|l|}{ K1: Data architecture } \\
\hline $\begin{array}{l}\text { 1. Data are defined consistently based on simple } \\
\text { vocabulary }\end{array}$ & 5 & 5 & 4 & 4 & 5 & 5 & 4 & 4 & 5 & 4.56 & 0.527 & $\begin{array}{l}\text { Accepte } \\
\quad \mathrm{d}\end{array}$ \\
\hline $\begin{array}{l}\text { 2. Data analysis is performed to elicit useful } \\
\text { information }\end{array}$ & 5 & 5 & 5 & 5 & 5 & 5 & 5 & 5 & 5 & 5 & 0.000 & $\begin{array}{l}\text { Accepte } \\
\mathrm{d}\end{array}$ \\
\hline \multicolumn{13}{|l|}{ K2: Data management principles } \\
\hline $\begin{array}{l}\text { 1. Data can be accessed according to the allowable } \\
\text { access rights }\end{array}$ & 4 & 5 & 4 & 5 & 5 & 5 & 5 & 5 & 5 & 4.78 & 0.441 & $\begin{array}{c}\text { Accepte } \\
\mathrm{d}\end{array}$ \\
\hline $\begin{array}{l}\text { 2. Data can be easily searched, identified, and } \\
\text { documented }\end{array}$ & 5 & 5 & 5 & 4 & 5 & 5 & 5 & 5 & 5 & 4.87 & 0.333 & $\begin{array}{l}\text { Accepte } \\
\mathrm{d}\end{array}$ \\
\hline 3. Data can be saved and reused & 5 & 5 & 5 & 5 & 5 & 5 & 5 & 5 & 5 & 5 & 0.000 & $\begin{array}{l}\text { Accepte } \\
\mathrm{d}\end{array}$ \\
\hline $\begin{array}{l}\text { 4. Data can be managed by the management } \\
\text { steward or data custodian }\end{array}$ & 4 & 5 & 4 & 5 & 4 & 5 & 5 & 4 & 5 & 4.87 & 0.527 & $\begin{array}{c}\text { Accepte } \\
\mathrm{d}\end{array}$ \\
\hline $\begin{array}{l}\text { 5. Data quality control is needed to ensure data will } \\
\text { be consistent, accurate, available, and complete }\end{array}$ & 5 & 5 & 5 & 5 & 5 & 5 & 5 & 5 & 5 & 5 & 0.000 & $\begin{array}{c}\text { Accepte } \\
\mathrm{d}\end{array}$ \\
\hline 6. Data access must support audit trails & 5 & 5 & 5 & 5 & 5 & 5 & 5 & 5 & 5 & 5 & 0.000 & $\begin{array}{c}\text { Accepte } \\
\mathrm{d}\end{array}$ \\
\hline \multicolumn{13}{|l|}{ K3: Data lifecycle management } \\
\hline 1. Acquisition and selection process & 5 & 5 & 5 & 5 & 5 & 5 & 5 & 5 & 5 & 5 & 0.000 & $\begin{array}{l}\text { Accepte } \\
\mathrm{d}\end{array}$ \\
\hline 2. Access, utilization, and dissemination process & 4 & 5 & 5 & 5 & 4 & 5 & 5 & 5 & 5 & 4.78 & 0.441 & $\begin{array}{c}\text { Accepte } \\
\mathrm{d}\end{array}$ \\
\hline 3. Analysis, evaluation, and visualization process & 5 & 5 & 5 & 4 & 5 & 4 & 5 & 5 & 4 & 4.67 & 0.500 & $\begin{array}{c}\text { Accepte } \\
\mathrm{d}\end{array}$ \\
\hline 4. Archiving process & 4 & 5 & 5 & 5 & 4 & 5 & 5 & 5 & 5 & 4.78 & 0.441 & $\begin{array}{c}\text { Accepte } \\
\mathrm{d}\end{array}$ \\
\hline 5. Verification process and data cleaning & 5 & 5 & 5 & 5 & 5 & 5 & 5 & 5 & 5 & 5 & 0.000 & $\begin{array}{l}\text { Accepte } \\
\quad \mathrm{d}\end{array}$ \\
\hline 6. Data maintenance process & 5 & 5 & 5 & 4 & 5 & 4 & 5 & 5 & 4 & 4.67 & 0.500 & $\begin{array}{c}\text { Accepte } \\
\mathrm{d}\end{array}$ \\
\hline \multicolumn{13}{|l|}{ K4: Policy and procedure } \\
\hline 1. Explanation of data ownership & 5 & 5 & 5 & 5 & 5 & 5 & 5 & 5 & 5 & 5 & 0.000 & $\begin{array}{c}\text { Accepte } \\
\mathrm{d}\end{array}$ \\
\hline 2. Explanation of data saving and security & 5 & 5 & 5 & 5 & 5 & 5 & 5 & 5 & 5 & 5 & 0.000 & $\begin{array}{c}\text { Accepte } \\
\mathrm{d}\end{array}$ \\
\hline $\begin{array}{l}\text { 3. Explanation of responsibilities and parties } \\
\text { concerned }\end{array}$ & 4 & 5 & 5 & 5 & 5 & 5 & 5 & 5 & 5 & 4.89 & 0.333 & $\begin{array}{c}\text { Accepte } \\
\mathrm{d}\end{array}$ \\
\hline 4. Definition of used terminology & 4 & 5 & 4 & 4 & 4 & 5 & 5 & 5 & 5 & 4.56 & 0.527 & $\begin{array}{l}\text { Accepte } \\
\mathrm{d}\end{array}$ \\
\hline 5. Explanation of the rights for data access & 5 & 5 & 4 & 5 & 5 & 5 & 5 & 5 & 4 & 4.78 & 0.441 & $\begin{array}{l}\text { Accepte } \\
\mathrm{d}\end{array}$ \\
\hline
\end{tabular}


INTERNATIONAL JOURNAL OF ACADEMIC RESEARCH IN BUSINESS AND SOCIAL SCIENCES

Vol. 8, No. 9, Sept. 2018, E-ISSN: 2222-6990 @ 2018 HRMARS

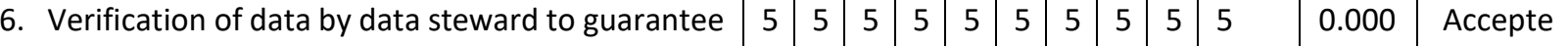
the quality and integrity of data

K5: Metadata

1. Versatility (Metadata have multi functions)

2. Modularity (Metadata can be divided into submodules)

3. Extensibility (Metadata can support addition of elements)

4. Granularity (Levels of metadata can be explained)

5. Platform (Metadata can function on the latest platform)

K6: Support services

1. Support for automatic data management for all service departments

2. Support for data collection by authorized parties

3. Support for duplicated offsite data, such as mirror duplicates, Data Recovery Center (DRC) or external data (kept by external agencies)

4. Support for policy related to data duplication

\begin{tabular}{|c|c|c|c|c|c|c|c|c|c|c|c|}
\hline 4 & 4 & 5 & 5 & 4 & 5 & 5 & 5 & 5 & 4.67 & 0.500 & $\begin{array}{c}\text { Accepte } \\
d\end{array}$ \\
\hline 4 & 4 & 5 & 5 & 4 & 4 & 5 & 5 & 5 & 4.56 & 0.527 & $\begin{array}{c}\text { Accepte } \\
d\end{array}$ \\
\hline 5 & 4 & 5 & 5 & 5 & 5 & 4 & 4 & 5 & 4.67 & 0.500 & $\begin{array}{c}\text { Accepte } \\
d\end{array}$ \\
\hline 5 & 4 & 4 & 5 & 4 & 4 & 4 & 5 & 5 & 4.44 & 0.527 & $\begin{array}{c}\text { Accepte } \\
d\end{array}$ \\
\hline
\end{tabular}

\section{K7: Data sources}

1. Data are shared assets

2. Data sources and data integrity need to be maintained and protected

3. Data have to be managed as important sources for organizations to help maintain the quality and standard of data

K8: Assessment - data maturity model

1. Level 1: Unaware (Data are limited and the accuracy and validity of data are not checked)

2. Level 2: Nascent (Data collection is good, but the collected data are not consistent and hardly updated)

3. Level 3: Learning (Studies on the value, relevancy, and usage of data are performed despite some minor data errors)

4. Level 4:Developing (The needs for data are defined and collected systematically)

5. Level 5: Mastering (Values and usage of data are well-understood)

\section{K9: Security and access}

1. Data have can be shared and accessed

2. Data security is based on the level of data complexity

\begin{tabular}{|c|c|c|c|c|c|c|c|c|c|c|c|}
\hline 5 & 4 & 5 & 5 & 5 & 5 & 5 & 5 & 5 & 4.89 & 0.333 & $\begin{array}{c}\text { Accepte } \\
\text { d }\end{array}$ \\
\hline 5 & 4 & 4 & 5 & 4 & 4 & 4 & 5 & 5 & 4.44 & 0.527 & $\begin{array}{c}\text { Accepte } \\
\text { d }\end{array}$ \\
\hline 5 & 4 & 4 & 5 & 5 & 5 & 5 & 5 & 5 & 4.78 & 0.441 & $\begin{array}{c}\text { Accepte } \\
\text { d }\end{array}$ \\
\hline 5 & 4 & 5 & 5 & 4 & 5 & 5 & 5 & 5 & 4.78 & 0.441 & $\begin{array}{c}\text { Accepte } \\
\text { d }\end{array}$ \\
\hline
\end{tabular}

\begin{tabular}{|c|c|c|c|c|c|c|c|c|c|c|c|}
4 & 5 & 4 & 5 & 5 & 5 & 5 & 5 & 5 & 4.78 & 0.441 & $\begin{array}{c}\text { Accepte } \\
d\end{array}$ \\
\hline 5 & 5 & 5 & 5 & 5 & 5 & 5 & 5 & 5 & 5 & 0.000 & $\begin{array}{c}\text { Accepte } \\
d\end{array}$ \\
\hline 5 & 5 & 5 & 5 & 5 & 5 & 5 & 5 & 5 & 5 & 0.000 & $\begin{array}{c}\text { Accepte } \\
d\end{array}$ \\
\hline
\end{tabular}

d)

\begin{tabular}{|l|l|l|l|l|l|l|l|l|l}
5 & 4 & 4 & 4 & 4 & 3 & 4 & 4 & 4 & \\
\hline 4 & 4 & 4 & 4 & 4 & 4 & 4 & 4 & 4 & \\
\hline 4 & 4 & 4 & 4 & 4 & 4 & 4 & 4 & 4 & \\
5 & 4 & 4 & 5 & 5 & 5 & 5 & 5 & 5 \\
5 & 4 & 4 & 5 & 5 & 5 & 5 & 5 & 5
\end{tabular}

\begin{tabular}{|l|c|c|}
\hline 4 & 0.500 & $\begin{array}{c}\text { Accepte } \\
\text { d }\end{array}$ \\
\hline 4 & 0.000 & $\begin{array}{c}\text { Accepte } \\
\text { d }\end{array}$ \\
\hline 4 & 0.000 & $\begin{array}{c}\text { Accepte } \\
d\end{array}$ \\
\hline 4.78 & 0.441 & $\begin{array}{c}\text { Accepte } \\
d\end{array}$ \\
\hline 4.78 & 0.441 & $\begin{array}{c}\text { Accepte } \\
d\end{array}$ \\
\hline
\end{tabular}

\begin{tabular}{|c|c|c|c|c|c|c|c|c|c|c|c|}
5 & 5 & 5 & 5 & 5 & 5 & 5 & 5 & 5 & 5 & 0.000 & $\begin{array}{c}\text { Accepte } \\
d\end{array}$ \\
\hline 5 & 5 & 5 & 5 & 5 & 5 & 5 & 5 & 5 & 5 & 0.000 & $\begin{array}{c}\text { Accepte } \\
d\end{array}$ \\
\hline
\end{tabular}




\begin{tabular}{|l|c|c|c|c|c|c|c|c|c|c|c|c|c|c|c|c|c|c|c|}
\hline 3. Confidential data have to be encrypted & 5 & 5 & 5 & 5 & 5 & 5 & 5 & 5 & 5 & 5 & 0.000 & $\begin{array}{c}\text { Accepte } \\
d\end{array}$ \\
\hline $\begin{array}{l}\text { K10: Disasters management } \\
\text { 1. Phase 1: Assessment of disasters }\end{array}$ & 5 & 5 & 5 & 5 & 5 & 5 & 5 & 5 & 5 & 5 & 0.000 & $\begin{array}{c}\text { Accepte } \\
d\end{array}$ \\
\hline $\begin{array}{l}\text { 2. Phase 2: Activation of recovery plans } \\
\text { 3. Phase 3: Operational replacement } \\
\text { platform/recovery of main platform }\end{array}$ & 5 & 5 & 5 & 5 & 5 & 5 & 5 & 5 & 5 & 5 & 0.000 & $\begin{array}{c}\text { Accepte } \\
d\end{array}$ \\
\hline 4. Phase 4: Testing and maintenance & 5 & 5 & 5 & 5 & 5 & 5 & 5 & 5 & 5 & 5 & 0.000 & $\begin{array}{c}\text { Accepte } \\
d\end{array}$ \\
\hline
\end{tabular}

In the second round of the process of the Delphi method, 10 components and 44 elements were validated that had to be embedded in the critical data management framework. Initially, only eight components were identified, namely data architecture, data management principle, data lifecycle management, policy and procedure, metadata, support services, data sources, and assessment - data maturity model. Later, another two new components were added to the proposed framework, namely security and access and disasters management. The following are the details of each element for each component (listed from the highest to the lowest mean scores).

(a) Security and access (K9) and disasters management (K10) were rated to be the two most important components for the proposed framework for critical data management, with each component attaining a mean score of 5.00, which was the maximum score. Initially, the security and access component was not listed in the assessment instrument, given the lack of emphasis on this component in previous studies (Beaujardiere, n.d.; Kaur \& Shah, 2017). Likewise, the disasters management component was also not included in the assessment instrument, as existing frameworks are mainly designed for general data management which does not require such a component (Beaujardiere, n.d.; Patricia, 2014). Furthermore, only a handful of organizations have actually emphasized this component in their data management practices (Mohamed, 2014). Interestingly, the findings of the first round showed that three experts had stressed the importance of these two components of critical data management in dealing with disasters. Such emphasis is hardly new as several researchers had highlighted the importance of these two components in previous studies (Smith, 2011; Mohamed, 2014). Thus, as recommended, these two new, critical components were added to the proposed framework.

(b) Data management principles (K2) and data sources (K7) were rated as the second most important components, with both registering impressive range of mean scores, ranging from 4.78 to 5.00. Effectively, this finding suggests that all experts were in total agreement with regard to the importance of these two components for critical data management framework. Again, such a finding is consistent with the findings reported in the literature (Beaujardiere, n.d.; Patricia, 2014; Ketchum, 2016; GEO Data Management Principles Task Force, 2015).

(c) Data lifecycle management (K3) was rated to be the third most important component for the proposed framework for critical data management, made evident by the high mean scores of 
all of its elements, ranging from 4.67 to 5.00. Clearly, this component is vital as it involves a critical process of managing data from the start (data acquisition) to the end (data maintenance). The high rating of this component seems to be in line with the contentions of Beaujardiere, (n.d.), Patricia, (2014), Ketchum (2016), and GEO Data Management Principles Task Force (2015), emphasizing its critical role in managing critical data.

(d) The fourth most important components were data architecture (K1) and policy and procedure (K4), with each component scoring a range of high mean scores, ranging from 4.56 to 5.00 . For the latter, three out of six elements achieved maximum mean scores of 5.00. Such scores clearly underline the importance of this component that must be embedded in the proposed framework. Again, this finding is consistent with the findings of Nor Hasbiah et al.'s (2017) and Douglas's (2014) studies in which they concluded that data architecture and operating procedure (SOP) must be given strong emphasis for effective data management. The call for such SOP is critical to the management of organizations' data, which is in line with Gidey's (2012) assertion, stating that "the standard operating procedure, if realized and materialized as a component of an effective management system, helps cultivate transparent functions, implement error prevention measures, facilitate corrective actions, and transfer knowledge and skill".

(e) The fifth most important component was support services (K6) that was rated highly important by the experts, as attested by a range of high mean scores of its elements, ranging from 4.44 to 4.89 . In this study, two new elements were added to the framework as suggested by two experts during the first round of the process of Delphi method, namely off-side data, such as duplicates mirror, Data Recovery Center (DRC), and external data (kept by external agencies), and data duplication policy, both of which attained a mean score of 4.78 , suggesting that their importance is also as vital as the other elements. In fact, these two elements had been identified to be important for data management in a pilot study conducted by Nor Hasbiah et al. (2017); however, they were not included in the first round of the process of the Delphi method in this study due to the lack of evidence reported in the literature. As anticipated, in this round, the panel of experts strongly recommended the inclusion of these elements in the assessment instrument. Accordingly, these elements were added to the assessment instrument for the second round of the validation process. Evidently, their inclusion in the instrument as important elements paid dividends, as highlighted by a high mean score of 4.78 .

(f) The sixth most important component was metadata (K5), with its elements attaining a range of high mean scores, ranging from 4.44 to 4.47. More revealingly, all its elements were unanimously accepted to be highly important by all experts. Such finding is to be expected because this component is regarded to be a vital component in most common data management frameworks (Beaujardiere, n.d.; Patricia, 2014; Ketchum, 2016; GEO Data Management Principles Task Force, 2015). Despite its importance, metadata has not been included in many critical data management frameworks, which may be partly attributed to the general consensus that it merely shows about data, and nothing more.

(g) The least rated element was data assessment (K8), with its elements attaining a range of mean scores, ranging from 4.00 to 4.78 . For this component, all its elements were accepted to be important by the panel of excerpts in both rounds of the Delphi method. In fact, the elements of this component could be categorized into two perspectives, namely the 
stakeholders' perspective and the perspective of the data itself. Probably, its relatively low rating (in relation to those of other components) may be partly attributed to this dichotomy of perspectives, with the experts assessing its importance solely from the data perspective. The experts might have no prior knowledge about the elements related to the stakeholders' perspective to allow them to make a more comprehensive assessment of all its elements.

Through the implementation of the Delphi method, 10 components and 44 elements had been validated by the panel of experts that helped the researchers to formulate the appropriate critical data management framework to deal with any situation facing disasters as depicted in Figure 2 . Effectively, the proposed framework consists of data architecture, data management principles, data lifecycle management, policy and procedure, metadata, support services, data sources, assessment - data maturity model, security and access, and disasters management.

\section{Recommendations}

In this study, a framework was formulated consisting of relevant components that had been validated by a panel of experts through the Delphi method. This framework is called the critical data management framework to deal with any situation facing disasters as illustrated in Figure 2. Specifically, this proposed framework contains all required features, components, and elements deemed critical from the standpoint of highly experienced practitioners, notably data managers, ICT administrators, and academicians, whose feedback would enable the researchers to build an efficient prototype system, which would be called e-BRP, based on the proposed critical data management framework. Surely, with improved critical data management efficiency, organizations could reap the potential benefits of the proposed system prototype in managing their critical data, thus improving their current practice over the long term. 
INTERNATIONAL JOURNAL OF ACADEMIC RESEARCH IN BUSINESS AND SOCIAL SCIENCES

Vol. 8, No. 9, Sept. 2018, E-ISSN: 2222-6990 @ 2018 HRMARS

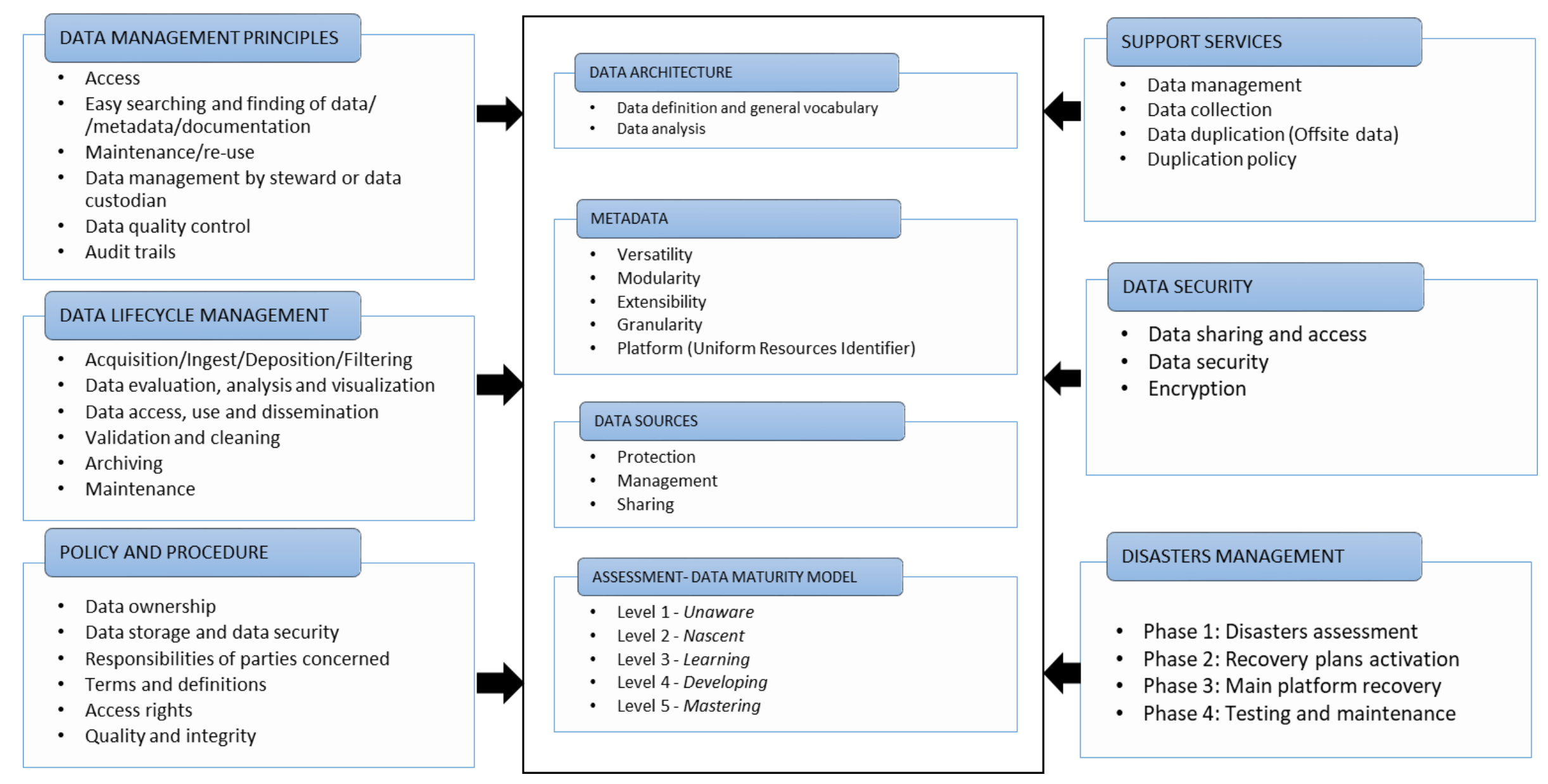

Figure 2: A Critical Data Management Framework for situations facing disasters 
INTERNATIONAL JOURNAL OF ACADEMIC RESEARCH IN BUSINESS AND SOCIAL SCIENCES Vol. 8, No. 9, Sept. 2018, E-ISSN: 2222-6990 @ 2018 HRMARS

\section{Conclusion}

In this study, the Delphi technique was used to validate the components and elements of a critical data management framework that can help improve the process of managing data in situations facing disasters. This iterative technique was chosen given its proven utility in identifying, analyzing, and verifying relevant components and elements in many studies of such nature. As such, two rounds of the technique were carried out to collect and analyze opinions elicited from a panel of nine (9) multidisciplinary experts in data management. At the completion of the second round, a consensus was reached, highlighting 10 components and 44 elements that were deemed critical for the formulation of such a framework. Arguably, the development of the proposed framework could be employed to help further improve the current data management practice, especially in critical situations.

This study contributes to the formulation of a critical data management framework in situations facing disasters. One of the framework components, namely a disasters management could help organizations manage their critical data in critical situations. The framework can be used as a guideline to better manage a critical data, especially in situations facing disasters.

\section{Acknowledgments}

The authors would like to acknowledge the support of the Ministry of Education of Malaysia for the Fundamental Research Grant Scheme (FRGS) research grant and the assistance given by the Research and Management Centre, Universiti Pendidikan Sultan Idris, Tanjung Malaim, Perak Malaysia for the successful completion of this study.

\section{Corresponding Author}

Nor Hasbiah Ubaidullah

Associate Professor

Computing Department, Faculty of Arts, Computing and Creative Industry, Universiti Pendidikan Sultan Idris, 35900 Tg. Malim Perak, Malaysia

E-mail address: hasbiah@fskik.upsi.edu.my

\section{References}

Armstrong, J. S. (1985). Long range forecasting: from crystal ball to computer (2 ${ }^{\text {nd }}$ ed.). New York: John Wiley \& Sons Inc.

Australian National Data Service. (2017). Creating a data mangement framework. Retrieved January 10 2017, from https://www.ands.org.au/guides/creating-a-data-management-framework.

Beaujardière, J. D. (n.d.). NOAA environmental data management framework (1.0 $0^{\text {st }}$ ed.). Retrieved from https://nosc.noaa.gov/EDMC/documents/NOAA EDM Framework v1.0.pdf.

Brockhoff, K. (1975). The performance of forecasting groups in computer dialogue and face- to-face discussion. In Linstone, H. \& Turoff, M. (Eds.), The Delphi methods: technique and applications. London: Addison-Wesley.

Cagle, K. (2015). Understanding the big data life-cycle. Retrieved October 15 2017, from https://www.linkedin.com/pulse/four-keys-big-data-life-cycle-kurt-cagle. 
INTERNATIONAL JOURNAL OF ACADEMIC RESEARCH IN BUSINESS AND SOCIAL SCIENCES

Vol. 8, No. 9, Sept. 2018, E-ISSN: 2222-6990 @ 2018 HRMARS

Cantrill, J. A., Sibbald, B. \& Beutow, S. (1996). The Delphi and minimal group technique in health service research. International Journal of Pharmacy Practice, 4, 67-74.

Chu, H. C. \& Hwang, G. J. (2007). A Delphi-based approach to developing experts system with the cooperation of multiple experts. Experts System with Application, 1-15.

Cochran, S. W. (1983). The Delphi method: formulation and refining group judgments. Journal of Human Sciences, 2(2), 111-117.

Cuhls, K. (2014). Delphi method, Fraunhofer Institute for Systems and Innovation Research. Retrieved from http://www.unido.org/fileadmin/import/16959 DelphiMethod.pdf

Douglas, C. (2014). Technology \& information services: architecture principles (data principles).

Retrieved from

https://www.plymouth.ac.uk/uploads/production/document/path/4/4225/Architecture Princi ples v2.pdf

Egan, A. F. \& Jones, S. B. (1997). Determining forest harvest impact assessment criteria using expert opinion: A Delphi study. Northern Journal of Applied Forestry, 14(1), 20-25.

Erl, T., Buhler, P., \& Khattak, W. (2016). Big data fundamentals: concepts, drivers \& techniques.

Retrieved October 15 2017, from

http://www.informit.com/articles/article.aspx?p=2473128\&seqNum=11.

Gary, S. (2011). Can your district survive a data disaster? Retrieved July 27 2018, from http://www.asbointi.com.

GEO Data Management Principles Task Force. (2015). Data management principles implementation guidelines. Retrieved from https://www.earthobservations.org/documents/geo xii/GEO-

XII 10 Data Management Principles Implementation Guidelines.pdf.

Gidey, A. (2012). Reviewing the values of a standard operating procedure. Ethiop Journal Health Science, 22(3), 205-208.

Hai, L. T., Hai, P. H., Thai, C. L., Hugé, J., Ahenkan, A., Quynh, L. X., \& Van Hieu, V. (2011). Software for sustainability assessment: a case study in Quang Tri province, Vietnam. Environmental Modeling \& Assessment, 16(6), 541-550.

Haraguchi, M., \& Lall, U. (2015). Flood risks and impacts: A case study of Thailand's floods in 2011 and research questions for supply chain decision making. International Journal of Disaster Risk Reduction, 14, 256-272. http://doi.org/10.1016/j.ijdrr.2014.09.005i.

Mohamed, R. H. A. (2014). A proposed model for IT disaster recovery plan. International Journal of Modern Education and Computer Science, 4, 57-67. DOI:10.5815/ijmecs2014.04.08.

Hsu, C. C., \& Sandford, B. A. (2007). The Delphi technique: making sense of consensus. Practical Assessment Research \& Evaluation, 12(10). Retrieved January 22 2014, from http://pareonline.net/getvn.asp?v=12\&n=10.

Kaur, M., \& Shah, A. (2017). A novel framework for big data security infrastructure components. International Journal on Recent and Innovation Trends in Computing and Communication, 5(6). $\begin{array}{llll}\text { Retrieved } & \text { October } & 10 & 2017,\end{array}$ http://www.ijritcc.org/download/browse/Volume 5 Issues/June 17 Volume 5 Issue 6/1498 730590 29-06-2017.pdf\&p=DevEx.LB.1,5067.1

Ketchum, A. M. (2016). Guiding principles for data management: is your data FAIR? HSLS Update. Retrieved September 26 2017, from http://info.hsls.pitt.edu/updatereport/?p=9493. 
Kothari, C. R. (2004). Research methodology (2 ${ }^{\text {nd }}$ ed.). New Delhi: New Age International Publishers. Nor Hasbiah, U., Zulkifley, M., Aslina, S., Jamilah, H., Nazre, A. R., Mohamadisa, H. \& Saira Banu, O. K. (2017). The Current Practice of Data Management of Schools and District Education Offices: Is There a Need for a New Approach? International Journal of Academic Research in Business and Social Sciences, 7(11), 549-565.

Nworie, J. (2011). Using the Delphi technique in educational technology research. Tech Trends September, 55(5), 22-30.

Okoli, C. \& Pawlowski, S. D. (2004). The Delphi method as a research tool: an example, design considerations and applications. Information \& Management, 42, 15-29.

Patricia, C. (2014). The data management association - DAMA-DMBOK2 Framework. DAMA International. Retrieved from https://dama.org/sites/.../DAMA-DMBOK2-Framework-V220140317-FINAL.pdf.

Rowe, G. \& Wright, G. (1999). Expert opinions in forecasting: the role of the Delphi technique. Principles of Forecasting, 125-144. 